\title{
The Existence of Pawon Gondorasan Kasunanan Palace of Surakarta
}

\author{
Agung Purnomo $^{1 *}$ Dharsono $^{2} \quad$ Rustopo $^{3}$ Titis S. Pitana ${ }^{4}$ \\ 1.Faculty of Visual Art and Design, Indonesian Institute of the Art in Surakarta, Jln. K.H. Dewantara No.19, \\ Surakarta, Central Java, Indonesia \\ 2.Faculty of Visual Art and Design, Indonesian Institute of the Art in Surakarta, Jln. K.H. Dewantara No.19, \\ Surakarta, Central Java, Indonesia \\ 3.Faculty of Performing Art, Indonesia Institute of the Arts Surakarta. Ki HajarDewantara Road, No.19 \\ Kentingan, Jebres, Surakarta, Central Java, Indonesia \\ 4.The Architecture Department, The Sebelas Maret University in Surakarta, Jl. Ir. Sutami 36 Surakarta, Central \\ Java, Indonesia
}

\begin{abstract}
Kraton Kasunanan Surakarta (Kasunanan Palace of Surakarta) still holds on its tradition tightly so that such rituals as Wilujengan, Grebeg Suro, Sekatenan and Sewindhu are still held at large scale. Those traditions are inseparable from the role of the Court's pawon (kitchen) functioning as the place to provide a variety of meals and offerings. The spatial layout existing is adjusted with its function as the process from preparation, processing to serving the offering ready to be distributed to the ritual site. To discuss the existence, form, and function, the necessary data was collected using qualitative research method with an approach emphasizing on design appreciation and design interpretation. Pawon Gondorasan has typical form and function different from those of kitchen in general. The procession within it not only realizes a variety of offerings but also there is an agenda pertaining to religious aspect, spatial concept, symbol, and meaning. The Existence of Pawon Gondorasan was also affected by Javanese society's ontology concerning the reality, that were, the origin and the objective of reality, its perspective on the essence of human being and on God, and the human-God relation.
\end{abstract}

Keywords: existence, Pawon Gondorasan, tradition, rituals

DOI: $10.7176 / \mathrm{ADS} / 71-01$

Publication date:March $31^{\text {st }} 2019$

\section{Introduction}

Residence building will feel less complete when there is no kitchen (pawon) within it, because any daily logistical needs are prepared and processed there and then served to be the family meal. Similarly, the function of kitchen in the Court's building is basically as same as the place producing food, but its management is more complex due to many culinary types and needs and the procedure to deal with. The banquet rite to welcome the royal guest and the preparation of offering complements in the Court's customary rite involve the role of kitchen.

Kraton Kasunanan Surakarta (Surakarta Kasunanan Palace) has a variety of kitchens. Their existence plays an important part as the place where a variety of meals (culinary) is produced for ritual purpose, in this case offering (sesaji), profane purpose such as banquet. Pawon in the court develops and changes according to the condition of time. Paku Buwono X (The Tenth Paku Buwono) provided four kitchens: Pawon Ageng to cook the staples, Pawon Nyirosuman especially for cooking snack and keleman, Pawon Drowesono for processing beverages, and Pawon Kridowoyo for processing cow milk. During Paku Buwono XI's reign there was a different form of kitchen due to the change in meal and banquet, and appetite. There are two pawons: Pawon Pakubuwanan and Pawon Gondorasan formerly were Pawon Ageng, Pawon Nyirosuman, Pawon Drowesono, and pawon Kridowoyo.

Pawon Gondorasan is located behind kedaton constructed for an abdi dalem to undertake his/her duty of providing a variety of meals to be used as offering in ritual ceremony organized in the Court. Its shape is just like other Javanese house with the main spatial pattern consisting of pendhapa, pringgitan, and dalem. However this building has a different spatial layout concept for different function. In addition to the main spatial pattern, there is a supporting room consisting of two wide kitchens and two spatial rooms for the transit of Court's heirloom in the manifestation of cooking equipment before conducting the procession of preparing the meal for offering (sesaji). The spatial organization involves the layout of existing spatial connection and circulation connected integrally to the more macro spatial concept, the existence of Court implemented to any ritual ceremonies procession.

Pawon Gondorasan does not change considerably in both its function and its shape until today. This kitchen functions specifically for preparing a variety of offerings for the customary rites existing in the Court such as kemisan, mahesa lawung, jumenengan, sekaten, mauludan and sewindhu traditions occurring in Dal (Javanese) year. To run its function, Pawon Gondorasan has leadership and procedure specified by the Court. "Lurah" is an address for the household chief of Pawon Gondorasan, a woman designated by the Court for her experience and 
knowledge. The succession of lurah is conducted when the incumbent lurah has no longer been able to run her function due to age factor; this position is usually given to her daughter or other family members, for example, daughter in law. Lurah is responsible for the availability of various offerings; therefore he is helped by "sinoman" by distributing the job clearly. Their work involves buying the material, cooking certain meals requiring special skills and serving them in the palace.

There are many offerings prepared according to the need of ritual ceremonies to be held. For example, in "kemisan" rite conducted every kemis day (Thursday), the offerings that should be provide include: "pepak-alit" and "pepak-ageng". "Tumpeng sewu" offering always exists in every 'jumenengan' event. The event held once in 8 years, "sewindhu", occurring in "dhal" year (according to Javanese calendar) needs the "gunungan"-form offering.

The existence of Pawon Gondorasan with its any function, form and scope is a cultural phenomenon very interesting to study. Not only the concept of spatial layout is intended to fulfill the practical function but also it contains Javanese people's ontology concerning reality, the origin and objective of reality, its perspective on the essence of human being and on God and the human-God relation.

\section{Conceptual Framwork}

The Court neighborhood served as the governmental and cultural center in the past, in which hundreds people live within it, from those doing simple handwork, cleaning service officers sweeping the Palace's yard and interior and keeping it clean and shining, water carrier and etc to the craftsperson capable of producing handicraft and fine ceramic and the poets (book authors) using their very beautiful hand. This group involves some palace safeguard and special soldier units with the sturdy and muscular names such as tamtama, wirabraja, and etc. To support their and the royal family's logistic needs, the Court has its own income sources including certain areas supplying rice for the royal kitchen's need (Moertono, 1981).

In Kasunanan Palace of Surakarta during the Paku Buwono X's reign, the existence of court kitchen got much attention for serving the royal guest, so that at that time there were some types of kitchen such as Pawon Ageng to cook the staples, Pawon Nyirosuman especially for cooking snack and keleman, Pawon Drowesono for processing beverages, and Pawon Kridowoyo for processing cow milk. In addition, the King loved delicious meals. He often had any delicious meal served. It made him fat and called "the Big King" meaning the king with big body, rather than the king with large power (Sumodiningrat, 2014).

The need for kitchen in the Court is not only profane in nature, but also related to Javanese society's ontology concerning the reality, that were, the origin and the objective of reality, its perspective on the essence of human being and on God, and the human-God relation. To implement such the perspective, some rites are held: sekaten, gerebeg, labuhan and etc. in Gerebeg rite, Sultan releases gunungan as the symbol of the king's alms to his people eliciting bless. The form of gunungan is like ceremonial dish of yellow rice served in a cone shape symbolizing: the journey of human beings from birth to death (coming back to the Supreme Being, God), sangkan paraning dumadi (Endraswara, 2015). Gunungan is the offering processed and prepared previously in one type of kitchen existing in the Court. Gunungan Sekaten or Gunungan Grebeg Maulud is the culmination of event in sekaten celebration, composed of various feed and vegetables or staples. Gunungan symbolizes the king's giving to his people, so that it is distributed to the people in sekaten celebration (Lisbijanto, 2013).

Regarding interior design, some literature reviews will be explained. The word 'design' in Webster dictionary is defined as: initial idea, draft, planning, pattern, arrangement, plan, project, appropriate product, production, making, creating, preparing, composing, improving, thinking, goal, and clarity (Sachari, 1986). Supstandar said that design is a system prevailing for any types of planning emphasizing on an inseparable matter, but a unity in which one matter is interrelated to another.

\section{Discussion}

Etymologically, the word "pawon" in Javanese language is defined as: firstly, a house building specifically provided for cooking activities and, secondly a hearth. The word "pawon" derives from awu meaning ash, with affix $p a$ - and -an, meaning a place (container). Thus, pawon ( $p a+a w u+a n)$ means ash place (container). Gondorasan in Javanese language derives from two words: "gondo" and "roso". "Gondo" means "aroma" while "roso" means "taste". So it can be inferred that Pawon Gondorasan is a place to cook something (food) with aroma and taste. Most of meals processed in Pawon Gondorasan are used for offering purpose in the rites organized by the Court.

Pawon Gondorasan is located inside the Kasunanan Surakarta complex. Its position is close to other areas such as magangan, kedhaton, Court Museum, and baluwarti. Despite 4m-wall borders, those areas are still connected to Pawon Gondorasan through the available doors. Interspatial connection in the court is inseparable from the function of each building within it. 


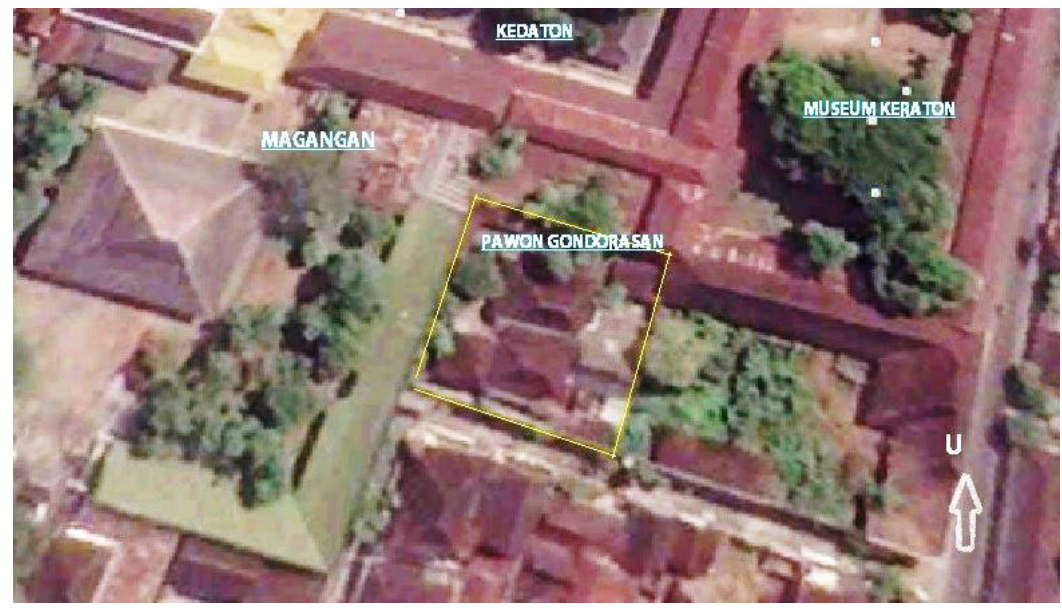

Figure 1. Site Plan of Pawon Gondorasan in the south of Kedaton as the center of Court. (Source: Google Maps) Pawon Gondorasan, as the Court's kitchen has a very important relation to Kedaton. As we know, the site plan of Surakarta Kasunanan Palace uses four-circle (concentric) concept as the guideline in the division of Court. The division includes: 1) First Circle, Kedhaton; 2) Second Circle, Baluwarti complex; 3) Third circle, Paseban; and 4) fourth Circle, Alun-alun. Thus, the innermost circle is Kedaton, followed with Baluwarti, Paseban and Alun-alun as the outermost. The central circle is the hub of circle that does not move but activates (dynamic power). This central position leads Kedaton to hold royal events including the rites requiring the ritual complements such as offering.

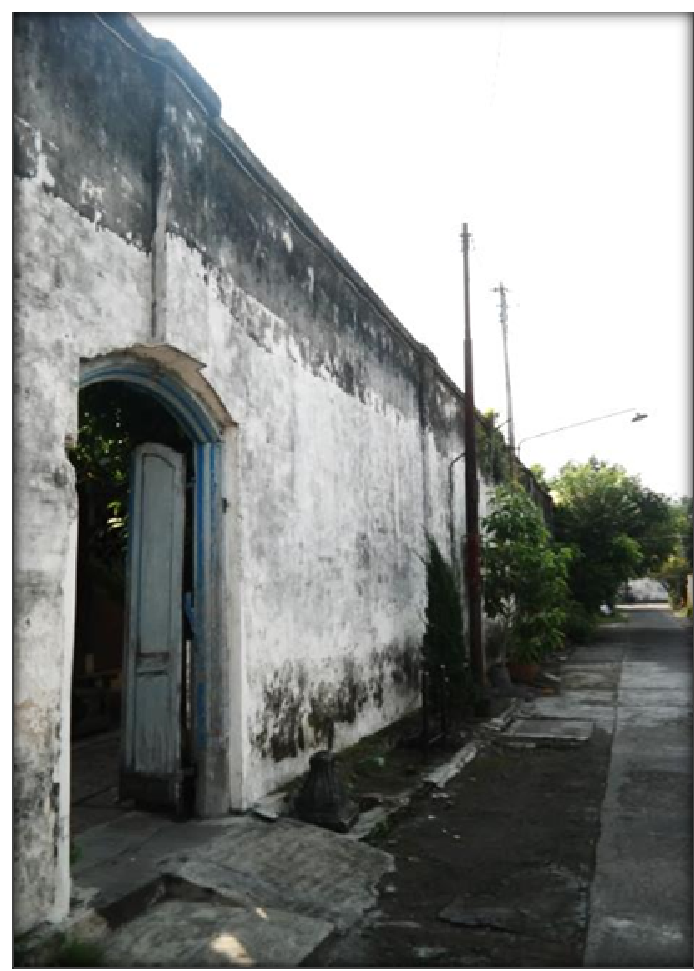

Figure 2. The Gate toward Pawon Gondorasan from the South.

(Photograph: Agung, 2016)

The characteristics of relationship between Pawon Gondorasan, and Kedhaton and others adjacent areas are affected by the type of rites held. The circulation occurring in the Court's rites pass through the access entrance not opened in any time, or opened at certain times only.

The activities in Pawon Gondorasan are led by a "lurah" called "Nyai Gondorasa". Since the Paku Buwono X's reign until today, there have been 9 successions of Pawon Gondorasan lurah from one generation to generation. There is a difference related to the lurah succession today. The $9^{\text {th }}$ Nyai Gondorasa has degraded in her ability due to age and health factor, but his daughters are not available to succeed her because they have worked in other places, consistent with their education background. For a moment, before the succession is held, most of her works are helped by Nyai Sekolanggen, the lurah of Pawon Sekolanggen, the Court's kitchen formerly functioned to provide the meal for the Court's soldier. Pawon Sekolanggen has no longer functioned 
duly due to the time change so that it is no longer needed, but its building is still maintained as the residence of Nyai Sekolanggen and her big family.

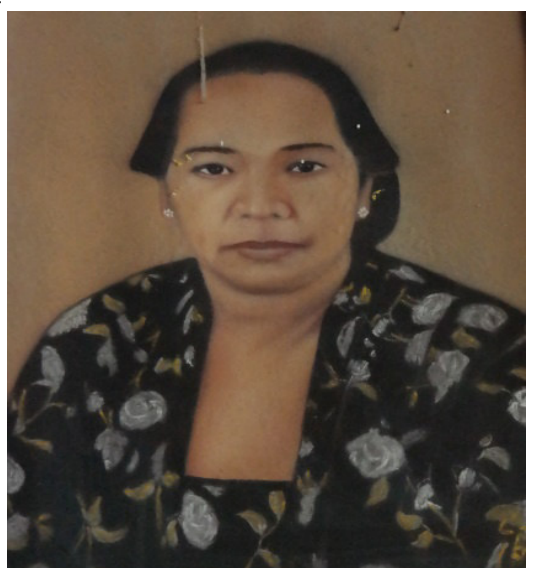

Figure 3. The Eighth Nyai Gondorasa (Photograph: Agung, 2016)

Surakarta Kasunanan Palace has routine ritual agenda requiring the offerings from Pawon Gondorasan. The rite held routinely weekly is Kemisan, and the one held every Selasa Kliwon (Kliwon day) is Anggoro Kasih. The rites held annually are: Suro, Sekaten, Jumenengan, Maesolawu, Bakdo Besar and Bakdo Sam. In addition, there is a Sewindhu rite held once in 8 years.

.........Ingkang rutin dinten Kamis (Kemisan) kaliyan Anggoro Kasih (Seloso Kliwon), sanesipun meniko menawi wonten Suro, Sekaten, Jumenengan, Maesolawu, Bakdo Besar, Bakdo Siam, kaliyan sewindhu 8 tahun sepindhah (Nanik Swaminarsih, 71 age years old, interview on April 16, 2018).

(...held routinely kemisan every Thursday and Anggoro Kasih every Selasa Kliwon, and other rites such as Suro, Sekaten, Jumenengan, Maesolawu, Bakdo Besar and Bakdo Siam, and sewindhu [once in 8 year]).

Every rite requires different offering in its form and types. Kemisan rite is held every Thursday in which pepak ageng and pepak alit offerings are provided.

Pepak ageng meniko wonten sak sekaran encek. Tiap pepak ageng wonten jajan pasar, tumpeng, bekakak, ketan-ketanan kalian ayam gesang. Setunggal paket pepak ageng wonten sekawan encek. Pepak alit nggih wonten nanging mboten mawi bekakak, mboten mawi ayam gesang, lajeng jajan pasar (Nanik Swaminarsih, 71 age years old, interview on April 16, 2018).

(...Pepak Ageng is arranged on the encek (a tray made of plaited bamboo). Every pepak ageng contains jajan pasar, tumpeng, bekakak (a meal made of glutinous rice resembling a couple of man and woman), and various meals made of glutinous rice and living chicken. A package of pepak ageng consists of four enceks. Pepak alit is similar to it, but with no bekakak and living chicken).

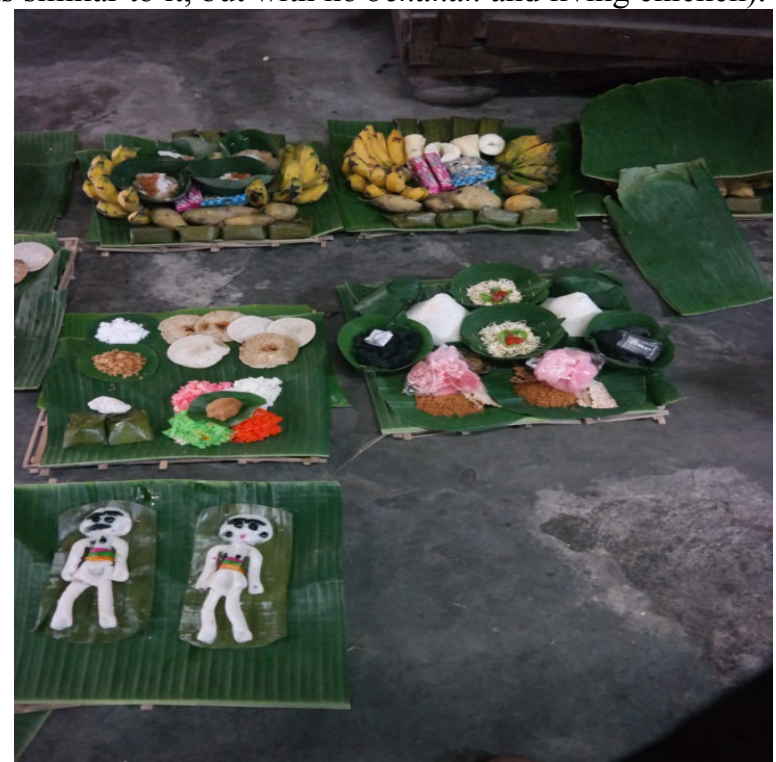

Figure 4. The offerings of pepak ageng completed (Photograph: Agung, 2016) 
The element in the offerings includes a variety of meals not changing over time. The change occurs in jajan pasar only, in which it is now packaged in plastic bag. For practical purpose, the jajan pasar in packaging is also included into sajen (offering).

........Jajan pasar kalih rumiyin sami mawon, sakmeniko pados gampilipun, pokokipun nopo isinipun pasar. Rumiyin kacangipun kacang godog, sakmeniko pados ingkang sampun dados. Buah menopomenopo kenging, buah sawo, buah rambutan nggih kenging. Kalau ketan-ketanan tidak boleh diganti, hanya itu. Ketan meniko abang, ijo, biru lajeng putih memplak, lajeng serabi merah kalian putih, itu dah seperti itu, tidak pernah diganti. Kalau jajan pasar apa adanya di pasar. Meniko mangke mawi pis pohong telo lajenglemet. Jajan pasar meniko kedah wonten pisang rojo, pohung telo. Sesaji saged dipesen tiyang ingkang kagungan kerso (Nanik Swaminarsih, 71 age years old, interview on April 16, 2018).

(...the present jajan pasar is as same as the past, but for practical purpose, it uses everything existing in the market. In the past, kacang godog [boiled peanut] is used, but now the ready-to-serve meal is used. It can be everything, sawo or rambutan fruit, for example. But the food made of glutinous rice (ketanan) cannot be replaced, because it is important. This ketanan is colored with red, green, blue, and white. There are also red and white serabi, all of which have never been replaced. There are also pis pohong telo and lemet. Jajan pasar should also contain raja banana, and cassava...)

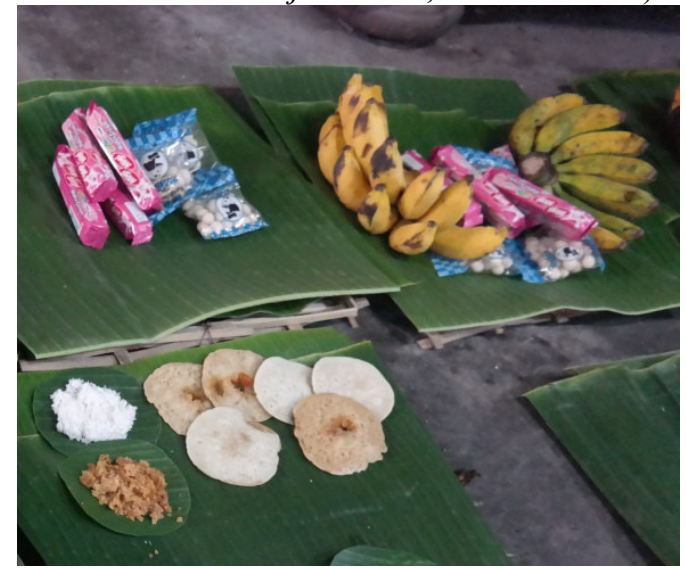

Figure 5. Offering using jajan pasar in plastic bag packaging (Photograph: Agung, 2016)

Having been prepared in Pawon Gondorasan, the offerings are then carried with becak (tricycle) passing through Baluwarti street toward the kamandhungan gate and then carried by the officers existing there into Kedhaton. Pepak ageng offering is put into Dalem Ageng Praba Suyasa intended to the heirloom in the form of "Tombak (lance)", while pepak alit to the heirloom Kyai Dudha existing in the kraton kilen (west Court) and some others is put before the Panggung Songgo Buwono.

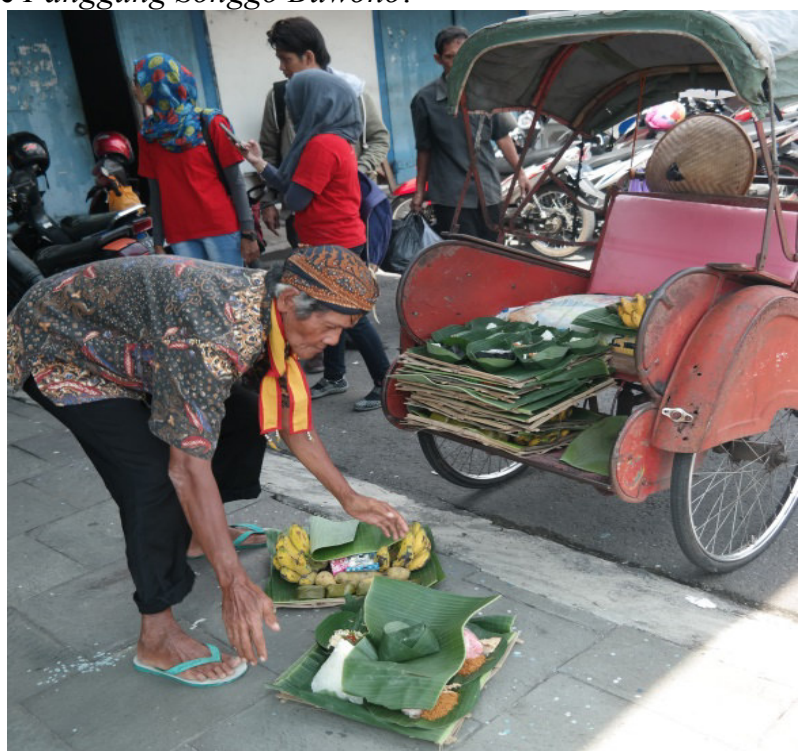

Figure 6. Sesajen (offering) is taken off from the tricycle

(Photograph: Agung, 2016) 
Tingalan Jumenengan Dalem rite is celebration of King Inauguration. In this event, Bedhaya Ketawang dance is performed; it is the sacred dance pertaining to Divinity in which everything will not occur without God's will. Some days before the Jumenengan rite, Bedhaya Dance practice is held in the Kedhaton; this activity is marked with the bustle in Pawon Gondorasan preparing the offering for the practice. The purchase of staples for midodareni eve or wilujengan purpose and the culmination of jumenengan have begun as well. The offering for Bedhaya Ketawang also contains jajan pasar.

......sesaji kagem Bedaya Ketawang meniko pisang setangkep njih lajeng mriki jajan pasar, lajeng mangke jenang abang, jenang putih ngaten, lajeng wonten koco kagem dandos penarine ngaten nggih, meniko kagem sesajinipun bedaya ketawang cacahipun meniko songo (Nyai Gondorasan, 74 age years old, interview on May 2 Mei, 2016).

(...the offering for Bedhaya Ketawang contains two bunches of banana, jajan pasar, jenang merah, jenang putih and then the mirror for the dancer's making up need. There are nine offerings for Bedhaya Ketawang).

On midodareni eve, wilujengan event is held in Kedhaton; at that time Pawon Gondorasan prepares tumpeng sewu to be served in the following day. The work of preparing tumpeng sewu containing a thousand tumpengs and various offering is done by sinomans from the evening to the daybreak. The job division has been obvious in which some sinomans cook rice for tumpeng, some other prepare kue apem, still some other prepare other types of offerings, all of which are under the coordination of Lurah Gondorasan, helped with Lurah Sekolanggen.

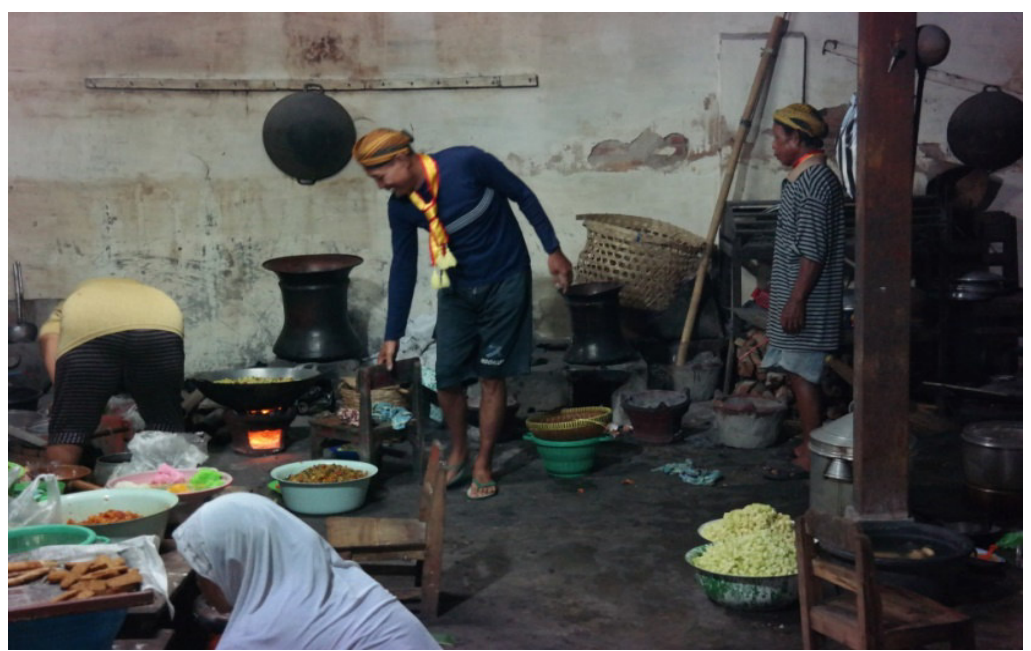

Figure 7. Cooking rice for tumpeng sewu using dhandhang conducted by the male sinoman. (Photograph: Agung, 2016)

........lajeng malem midodarenipun meniko ndamel tumpeng sewu Senin malem Seloso. Mriki wonten kotak cacahipun sekawandoso, setunggal kotak meniko isinipun tumpeng selangkung, lajeng enjang dipun pundhut dhateng kraton(Nyai Gondorasan, 74 age years old, interview on May 2 Mei, 2018).

(...then on the midodareni eve (Monday night), tumpeng sewu is prepared. In this room, there will be forty boxes, each of which contains twenty five tumpengs, to be carried to the Court).

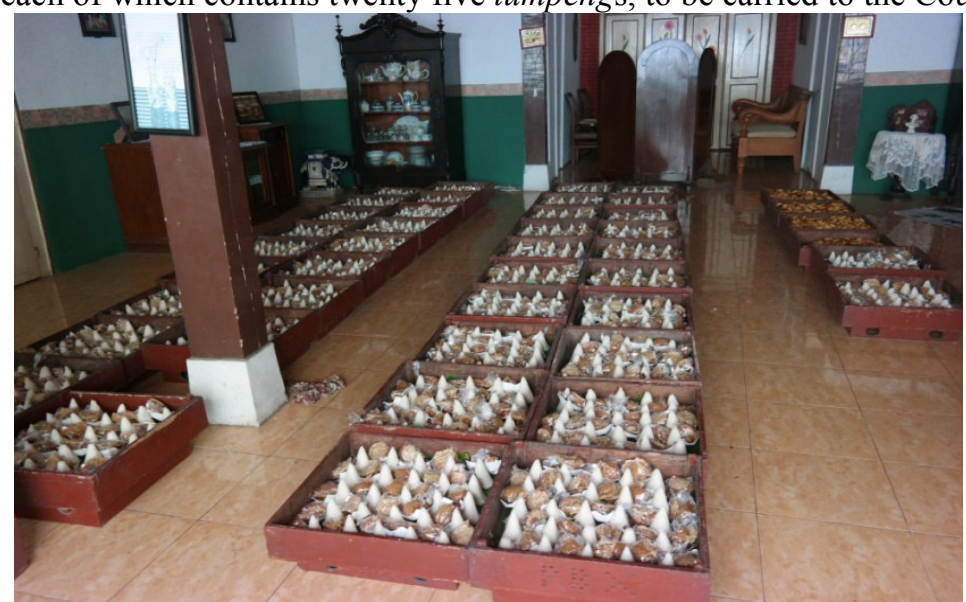

Figure 8. Tumpeng sewu and apem sewu are put in the pendhapa room of Pawon Gondorasan. (Photograph: Agung, 2016) 
In the morning, tumpeng sewu is brought into Kedhaton passing through Magangan to be served to the guest attending the Tingalan Jumenengan Dalem ceremony. The guests come from some former areas of Surakarta Kingdom such as Wonogiri, Karanganyar, and Boyolali.

......meniko inggih kathah saking Wonogiri, lajeng saking Karanganyar, Boyolali pokokipun daerah kekuasaan Kraton, ingkang pun utus sinten mriku... (Nyai Gondorasan, 74 age years old, interview on May 2 Mei, 2018).

(...in this case, many people come from Wonogiri, Karanganyar, Boyolali, constituting the areas of Court).

Tingalan Jumenengan Dalem customary rite is also held once in eight year (Sewindhu). The last Tingalan Jumenengan Dalem sewindhu was held on June 15, 2012 on Jumat Kliwon (Friday Kliwon), celebrating the inauguration of the Pakubuwono XIII, the $8^{\text {th }}$ Hangabehi. Such the Jumenengan held on Jumat Kliwon is the rare event repeated only once in 8 years (sewindhu).

For this rite, Pawon Gondorasan is given larger assignment and responsibility. In addition to preparing various offering needs, it should also prepare some special rooms for the cooking procession involving the King. Sewindhu rite is always related to the presence of "Kyai Dudha", the Court's heirloom in the form of dhandhang (a cooking appliance made of copper). The heirloom is stored inside the Court and it will exit or miyos along with its escorts to Pawon Gondorasan once in 8 years for a procession.

....Tahun Dal (8 tahun) pintu dibuka amargi Kanjeng Kyai Dudha miyos, barang2 didalaken. Sakral sanget, Raja simbolis ngesokaken beras dateng dandang Kyai dudha, saklajengipun dipun masak poro sinom. Kulo sampun kaping gangsal anemahi. Dandhang Kyai Dudha wonten penderekipun nggih meniko kenceng kangge ngaru, dandang malih, kendil ageng Kanjeng Kyai Rejeki, siwur kangge nyiduk. Pendhak Kemis kulo kan resik-resik ngrawat dipun paringi sekar. Kyai Dudha dipun blebet kain pethak lajeng dipun sampiri kain lurik Dengklung, cemeng mawi lerek-lerek. Lurik2 sanesipun wnten nanging wonten ngandap. Penderek-penderekipun namung diblebet kain pethak kemawon (Nanik Swaminarsih, 71 age years old, interview on April 16, 2018).

(...in Dal year (8 years) the door will be opened because Kanjeng Kyai Dudha comes, the objects will be released. It is very sacred, in which the King will pour the rice into dandhang Kyai Dudha symbolically, and then followed with the cook. Some other appliances such as kenceng for ngaru, other dandhang, big kendhil Kanjeng Kyai Rejeki and siwur to take some water follow dandhang Kyai Dudha. I clean and maintain them by giving them flower every Thursday. Kyai Dudha is wrapped with white cloth on which black stripped kain lurik Dengklung is hanged. The bottom part of another type of lurik cloth (kain lurik) is put on it as well. The escorts are wrapped with white cloth only...)

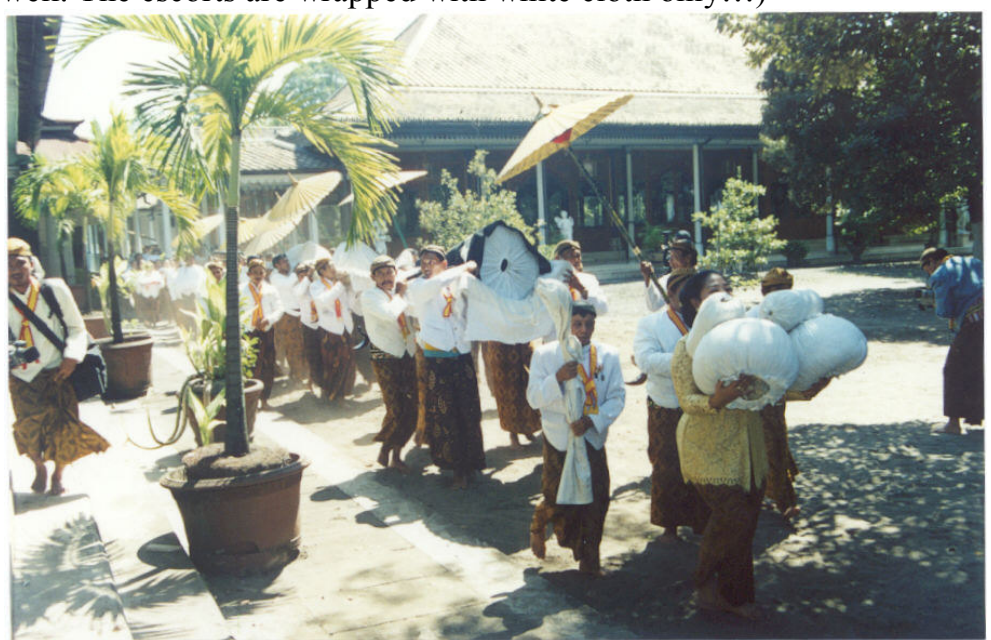

Figure 9. Carnival of Kanjeng Kyai Dudha and its escorts (pendherek) from inside the Court (kedhaton) to Pawon Gondorasan. (photograph: Sri Wuryani, 2006)

In Pawon Gondorasan, Kanjeng Kyai Dudha and its escort (pendherek) are put in a special room before the next procession (procession of bathing the heirloom/siraman) is held and the cooking procession is done in the kitchen prepared specifically. 


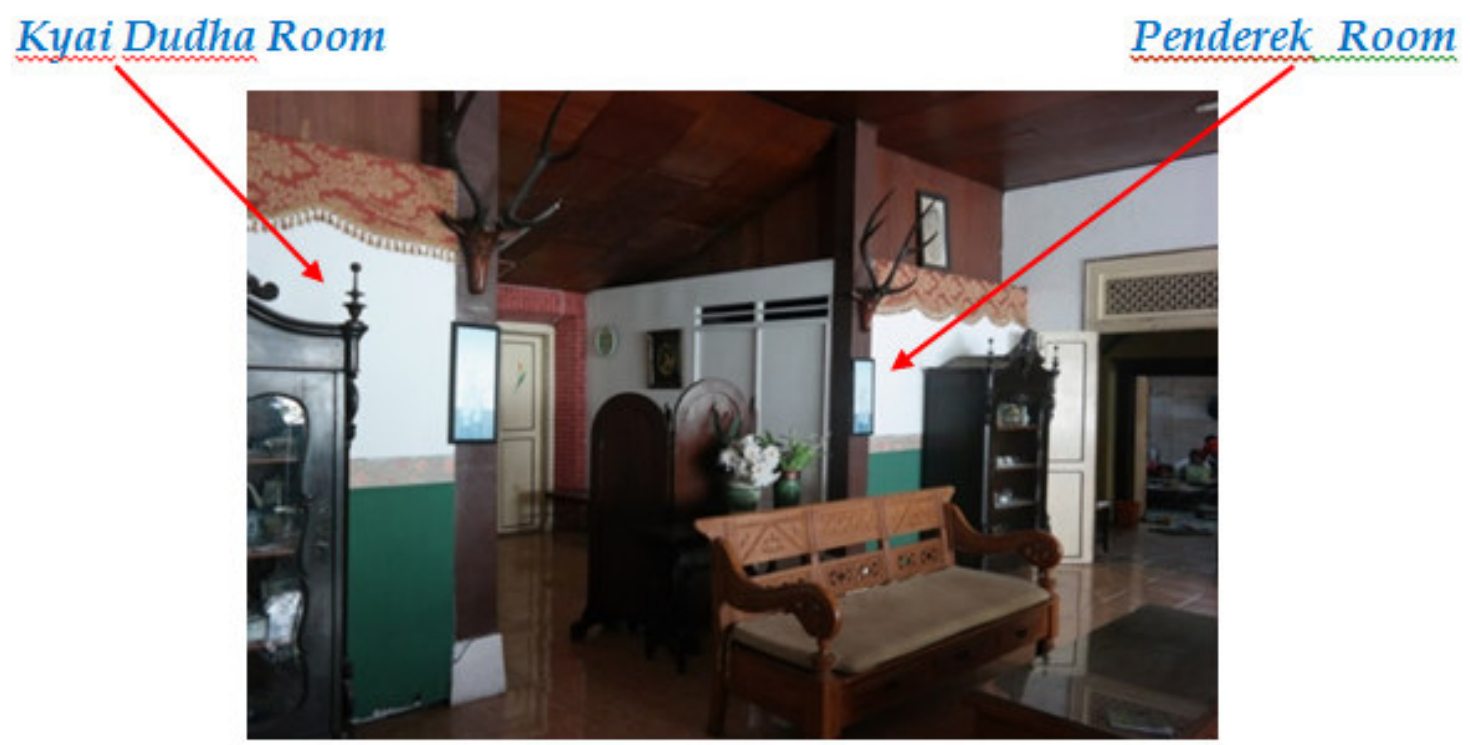

Figure 10. Center Room of Pawon Gondorasan as the temporary place for Kanjeng Kyai Dudha and its escort (pendherek). (Photograph: Agung, 2016)

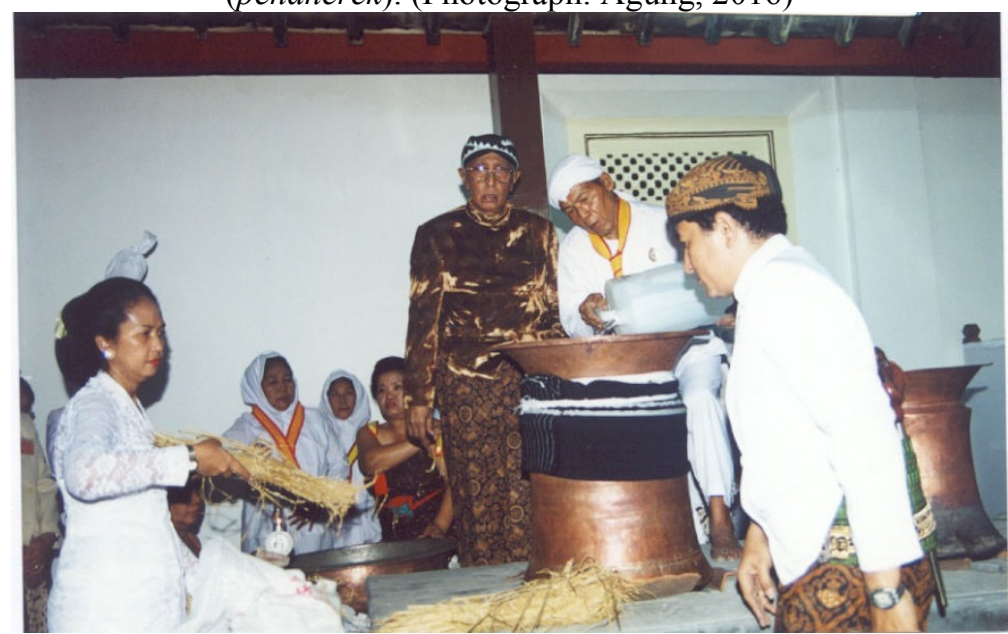

Figure 11. Gusti Kangjeng Ratu Alit and ISKS Pakoe Buwono XII, preparing the fire to cook rice; dandhang "Kyai Dudha" seems to be wrapped with "Dhengklung” motif-lurik cloth. (Photograph: Sri Wuryani, 2006)

Kyai Dudha in the physical form as the Court's heirloom has distinctive value for its supporting community. Its presence in a large event every 8 years, Tingalan Jumenengan Dalem, puts it onto special position. The object living in its community's thinking is always maintained in kemisan rite with offering as the form of respect because it is considered as having "power" that can provide virtuosity to the universe. After 8 years residing in the sacred Kedaton, it is time for Kyai Dudha to go out (miyos) to Pawon Gondorasan through the carnival procession with its greatness constituting the white holy cloth wrapped with "Dengklung" motif lurik cloth. The path taken is the one passing through Sasana Handrawina toward Magangan gate along with its escorts having distinctive labels just like the respected heirlooms. Those carrying the heirlooms are the Court's family and relative with abdi dalem escort. Having arrived at Pawon Gondorasan, Kanjeng Kyai Dudha heirloom takes a rest in the rooms provide specifically in the Pendhapa. The next procession is siraman, in which the pengageng Kraton bathed the heirlooms accompanied with the songs (tembang) as the form of prayer for the smoothness and the goodness in the rite held. The fire is turn on signing the procession of cooking rice using Kyai Dudha conducted by one members of the Court's member, followed with rice pouring by the King.

The steps of procession symbolize the human beings' journey toward the better life level in his/her relation to God as the Almighty and to his/her fellows and nature. Human life can give blessing to other human as natural environment as the source of life. For that reason, human being attempts to clean and to purify themselves in order to benefit the worlds thereby arriving at the God (Creator).

Kyai Dudha is also believed as related to a Javanese legend, the story of Dewi Nawang Wulan and Joko Tarub. Briefly, this story started with Dewi Nawang Wulan, one of seven fairies who was taking a bath in the lake, who could not fly because Joko Tarub has stolen her shawl and then she became Joko Tarub's wife. Dewi 
Nawang Wulan cooked rice everyday using dandhang. Joko Tarub broke their agreement that he was not allowed to open the dandhang when Dewi Nawang Wulan cooked rice. So, Dewi Nawang Wulan formerly cooked a string of rice to be one dandhang of cooked rice could no longer do that finally. The rice inside the barn was used up gradually and Dewi Nawang Wulan could find her shawl hidden by Joko Tarub in the rice barn. Eventually, Dewi Nawang Wulan could fly again leaving Joko Tarub and making him a "dudha (widower)".

\section{Conclusion}

Surakarta Palace in its glory time still had full authority of governing its area, so that many rites were held, even during PB X's reign, those activities became the part of strategy to get recognition for its rule. The power fluctuation and dynamics in the Court's area affected the infrastructures supporting the ceremonies held inside and kitchen is one of them.

During PB X's reign, there are many Pawon or kitchens to prepare either profane banquet or offering for sacred rites. As the Court's rule regresses and the time changes, some kitchens no longer function, for example, Pawon Sekolanggen formerly functioning to prepare the food for the Kingdom's soldiers.

The existence of Pawon Gondorasan remains to be needed until today to cater to a variety of rites held by the Court. It is a difficult and hard work for the organizer of Pawon Gondorasan, because each of rites has distinctive characteristics, both in each type of offerings needed and in the procession conducted. They often work overtime from the morning to the late night to complete their work timely and with good result.

Pawon Gondorasan is a building serving not only as the place to prepare a variety of offerings in the rites, but also having unforgettable cultural and historical values. Its existence is very important in maintaining the sustainability of tradition in Surakarta Kasunanan Palace as the part of Indonesian cultural heritage that should be preserved and developed in the attempt of solidifying the nation's self-identity.

\section{References}

Bayuadhy, Gesta. (2015). Tradisi-tradisi Adiluhung Para Leluhur Jawa, Yogyakarta, Publisher DIPTA, 176

Endraswara, Suwardi. (2015). Etnologi Jawa, Yogyakarta, Publisher CAPS, 112

Lisbijanto, Herry.(2013). SEKATEN, Yogyakarta, Publisher Graha Ilmu, 31

Moertono, Soemarsaid. (1981). Negara dan Usaha Bina Negara di Jawa Masa Lampau, Studi Tentang Masa Mataram II, Abad XVI Sampai XIX, Canada, Cornell Modern Indonesian Project, 73

Sachari, Agus. (1986). Paradigma Desain Indonesia, Pengantar Kritik, Jakarta, Publisher CV. Rajawali, 27

Suptandar, J. Pamudji.1999, Desain Interior, Pengantar Merencana Interior untuk Mahasiswa Desain Interior, Jakarta, Djambatan, 12

Sumodiningrat, Gunawan. (2014). Paku Buwono X, Yogyakarta, Publisher Narasi., 62

\section{Interview:}

- $\quad$ Nyai Sekolanggi, 71 age years old, interview on April 16, 2016

- $\quad$ Nyai Gondorasa, 74 age years old, interview on May 2 Mei, 2016 